\title{
Impact Of Education Program About Family Planning Among Yemeni Women On Their Knowledge In Sana'a City
}

\author{
Afrah M Al-Dubhani, Kawther A Fadel, Ahmed M Al-Haddad, Soad S Bayoumi \& Soad A Sharkawy \\ Division of Nursing Higher - Faculty of Medicine and Health Sciences - Sana'a University. \\ Public Health \& Community Medicine-Faculty of Medicine- Assiut University. \\ Community Medicine Department- Faculty of Medicine- Sana'a University. \\ Community Health Nursing Department- Faculty of Nursing- Assiut University.
}

\begin{abstract}
:
A rapid population growth is a burden on the resources of many developing countries. Unregulated fertility, which contributes to such situations, compromises the economic development and political stability of these countries. Contraceptive use is the lowest in Yemen where about 1 out of 5 married women of reproductive age use contraception. The study conducted to evaluate the impact of implementing an educational program of family planning upon Yemeni women at Sana'a City. Quasi-experimental research design was used. It was conducted in AlSabeen Hospital and Al-Olofi Center which included a sample of one hundred and forty women, divided equally into two groups: study group and control group (seventy for each group). The tool was used; contain sociodemographic data and women' knowledge about family planning. The main result of the present study, more than half of the control group $(57.1 \%)$ their age was between 30 years and less than 40 years and (40\%) of studied group and (45.7 $\%)$ of the control group had preparatory education. The number of pregnancies was (41.4\%) of the study group and (58.6\%) for the control group had three or more times. Unwanted pregnancy represented $(64.3 \%$ and $57.1 \%$ respectively) of both study and control group. Also women' knowledge had a poor score on pretest, improved to good score on immediate post test, and remaining good score with slight decrease on follow up test with highly statistically significant difference. The study recommended that FP program should involve men as well as women, and ensure all primary health care clinics provide counseling on FP.
\end{abstract}

\section{Keywords: Family planning, Control birth, Spacing, Contraception.}

\section{Introduction:}

A rapid population growth is a burden on the resources of many developing, countries. Unregulated fertility, which contributes to such situations, compromises the economic development and political stability of these countries. Therefore, many countries consider limiting population growth as an important component of their overall developmental goal to improve living standards and the quality of life (Almualm., 2007).

Family planning allows individuals and couples to anticipate and attain their desired number of children and the spacing and timing of their births. It is achieved through use of contraceptive methods and the treatment of involuntary infertility. A woman's ability to space and limit her pregnancies has a direct impact on her health and well-being as well as on the outcome of each pregnancy (Shaw, 2012).

Family planning clinics are sources of knowledge for birth spacing and help make known the benefits of spacing births. Access to family planning resources has led to the reduction of infant and maternal mortality, unwanted births, teen pregnancy, spread of STDs and HIV, and improve the overall health of mother, child, and, ultimately, the family unit (Gold et al., 2009).

In Yemen, women face enormous challenges and obstacles. Young girls are often married by the age of 8 and receive little more than a primary school education. The population number in Yemen was reported 23.69 millions persons in 2009, according to the IMF. In 2015, Yemen's population is expected to be 28.28 millions persons. Population density is 35 per square kilometer. Yemen's population growth rate $3 \%$ and maternal mortality ratio 366 per 100.000 live births in 2009. A Yemeni woman will bear, on average, seven children. One in 19 women dies in pregnancy, making Yemen's maternal and infant mortality rates among some of the highest in the world (Saleh, 2009 \& MOPHP, 2009 \& IMF, 2009). The aim of the present educational program is to increase a good knowledge of family planning methods and improve reproductive health and quality life, which will be capable of meeting the needs of the women and the family for good life.

Subject and method:

Study design:

Quasi-Experimental design was utilized in the study. 


\section{Setting:}

The study was conducted in Al-Olofi Center for Childhood and Motherhood and Al-Sabeen Hospital. They are located in Sana'a city, which is the capital of the Republic of Yemen.

\section{Sampling:}

The target populations for this research were women in the previous mentioned setting. The total number of the sample was 140 women which had been calculated based on the last statically reports of women attendant Al-Sabeen Hospital and Al-Olofi Center for Childhood and Motherhood (2996 women) and took $5 \%$ of them. The sample was divided equally into two groups (study group and control group; seventy women in each group), $50 \%$ from Al-Sabeen Hospital and 50\% from Al-Olofi Center. The sample was selected by a systematic random sample" every second woman comes to the maternal clinic outpatient took in our sample and stay to make interview with them".

\section{Tool of data collection :-}

A structured interview sheet was designed by the researcher to assess the study sample knowledge before application of the program, immediately after the program and in the follow-up after 3 months.

The interview sheet covered the following: Part 1) A Socio-demographic Characteristics of the sample

It includes personal and social data such as; age, level of education, occupational status, years of marriage, number of pregnancies, number of living children, unwanted pregnancies, number of previous abortions, and type of abortion.

Part 2) Assessment of women knowledge about family planning

It includes, sources of information, definition of family planning, ideal number of children, the ideal period between pregnancies, the ideal age for women to stop having more children, benefits and methods of family planning, contraceptive pills, intrauterine device (IUD), male condom, female barrier methods, contraceptive implants, and contraceptive injections.

\section{Scoring system :-}

The states of the studied sample knowledge in the pretest, immediate post-test, and in late follow-up test were judged as the following:

Poor $<50 \%$

F air 50\% $-<70 \%$

Good $=70+\%$.

(Kaliyaperumal, 2004 and EL-Houfey, 2007). who estimated the answer by taking points as; poor $(<50 \%)$, Fair $(50-<70 \%)$ and good $(70 \%+)$.

\section{Ethical consideration:}

The purpose of this study was explained for every interviewed individual of the studied sample. Women have ethical rights to participate or refuse participation in the study; oral consent was taken from all women who participated in the study to ensure active participation and cooperation during implementing of the program and informed that the information obtained will be confidential and used only for the purpose of the study.

\section{Educational program about family planning.}

\section{Content of instruction :-}

Instructional units were selected to be used. It is a flexible method in the field of learning, also, it allows evaluation. The researcher is designed in 3 sessions.

1- Session 1: Introduction \& Importance of family planning.

2- Session 2: Benefits of family planning.

- Benefits for the mothers.

- Benefits for the baby.

- Benefits for the whole family.

3- Session 3: Types and methods of family planning.

- Natural methods

- Chemical methods

- Non hormonal (mechanical Methods)

- Surgical Methods.

\section{Methods:}

The study was executed on two phases:

Phase (1): preparatory phase:

In this phase, the tools for data collection after reviewing the related literature were developed. Preparation of the education program, which took 4 months to write it after reviewing literatures and textbooks that consist of family planning subject. Obtaining the necessary approvals from the directors of Al-Olofi Center for Childhood and Motherhood and Al-Sabeen Hospital in order to collect the necessary date from selected departments and to gain their cooperation. Preparation of teaching aids to help and facilitate teaching to women such as blackboard, booklets, brochures, pamphlets, posters, data show and slides (this took one month).

\section{Pilot study:}

A pilot study was carried out before starting data collection on 20 women. Data obtained was analyzed manually. The aim of it was to test the clarity of the tool as well as the time needed to fulfill each questionnaire.

Phase (2): implementation phase:

Collection of data; an explanation of the purpose of the research was made to the participated women to gain their cooperation before starting data collection. The interview of the women took 15-30 minutes and the daily number of women was 4- 5 women. Data collection with the followed up the case study and control sample were done in 11 months from the end 
of $1 / 9 / 2011$ to the end of 30/8/2012.

Implementing the educational program: phase of delivery of an educational program, was implemented in the period of about 3 months for each group. The tested groups were divided into 5 groups each group 10-15 women. The subgroup was received the educational intervention program in 3 sessions for 3 days; each session was consumed about two hours to two hours and fifteen minutes per day. Two days off between the sessions. Motivations aids; the researcher tried to explain the importance of family planning by giving the attainders booklets, brochures, male condoms, and breakfast with drinks after every interview and during the break of the sessions.
Moreover, the researcher gave the women and the calibrates staff certificates at the end of the program.

Data analysis :-

Data were coded and verified prior to computerized data entry. The statistical package of SPSS version 13 for windows was used for data entry. Descriptive statistics were calculated frequency, percentage, mean, standard deviation, chi- square test, F test, Pvalue less than 0.01 were considered as statistically highly significant while P- value less than 0.05 were considered as statistically significant. Participants' knowledge were assessed by a scoring system, scored of one grade was given for each correct answer and zero grade of each incorrect or don't answer

\section{Results:}

Table (1) Distribution of women (the control and study groups) regarding their socio demographic characteristics at Al-Sabeen Hospital and Al-Olofi Center, in Sana'a, 2011-2012.

\begin{tabular}{|c|c|c|c|c|}
\hline \multirow{3}{*}{ Items } & \multicolumn{4}{|c|}{ Group } \\
\hline & \multicolumn{2}{|c|}{ Control $(n=70)$} & \multicolumn{2}{|c|}{ "Study(n=70) } \\
\hline & No. & $\%$ & No. & $\%$ \\
\hline $\begin{array}{c}\text { Age: (years) } \\
<20 \\
20-<30 \\
30-<40 \\
40-<49\end{array}$ & $\begin{array}{l}1 \\
20 \\
40 \\
9\end{array}$ & $\begin{array}{l}1.4 \\
28.6 \\
57.1 \\
12.9\end{array}$ & $\begin{array}{l}4 \\
34 \\
23 \\
9\end{array}$ & $\begin{array}{l}5.7 \\
48.6 \\
32.9 \\
12.8\end{array}$ \\
\hline Mean \pm SD & \multicolumn{2}{|c|}{$2.81 \pm 0.666$} & \multicolumn{2}{|c|}{$2.53 \pm 0.793$} \\
\hline $\begin{array}{l}\text { Education status : } \\
\text { - Illiterate } \\
\text { - Read and write } \\
\text { - Preparatory education } \\
\text { - Secondary education } \\
\text {-Diploma \& Bachelor Degree }\end{array}$ & $\begin{array}{l}8 \\
6 \\
32 \\
16 \\
8\end{array}$ & $\begin{array}{l}11.4 \\
8.7 \\
45.7 \\
22.8 \\
11.4\end{array}$ & $\begin{array}{l}7 \\
10 \\
28 \\
20 \\
5\end{array}$ & $\begin{array}{l}10.0 \\
14.3 \\
40.0 \\
28.6 \\
7.1\end{array}$ \\
\hline $\begin{array}{l}\text { Occupation status: } \\
\text { - Housewife } \\
\text { - Employee } \\
\text { - Student } \\
\end{array}$ & $\begin{array}{l}56 \\
14 \\
0 \\
\end{array}$ & $\begin{array}{l}80.0 \\
20.0 \\
0.0\end{array}$ & $\begin{array}{l}50 \\
18 \\
2 \\
\end{array}$ & $\begin{array}{l}71.4 \\
25.7 \\
2.9\end{array}$ \\
\hline $\begin{array}{l}\text { Years of marriage: } \\
\quad<5 \\
5-<10 \\
10-<15 \\
15> \\
\end{array}$ & $\begin{array}{l}6 \\
24 \\
24 \\
16\end{array}$ & $\begin{array}{l}8.6 \\
34.3 \\
34.3 \\
22.8\end{array}$ & $\begin{array}{l}20 \\
20 \\
18 \\
12\end{array}$ & $\begin{array}{l}28.6 \\
28.6 \\
25.7 \\
17.1\end{array}$ \\
\hline $\begin{array}{l}\text { Number of living children: } \\
\text { None } \\
1-4 \\
5-6 \\
7+\end{array}$ & $\begin{array}{l}1 \\
39 \\
18 \\
12\end{array}$ & $\begin{array}{l}1.4 \\
55.7 \\
25.7 \\
17.2\end{array}$ & $\begin{array}{l}7 \\
42 \\
15 \\
6\end{array}$ & $\begin{array}{l}10.0 \\
60.0 \\
21.4 \\
8.6\end{array}$ \\
\hline
\end{tabular}


Table (2) Distribution of women (the control and study groups) regarding their obstetric history at Al-Sabeen Hospital and Al-Olofi Center, in Sana'a, 2011-2012.

\begin{tabular}{|c|c|c|c|c|}
\hline \multirow{3}{*}{ Items } & \multicolumn{4}{|c|}{ Group } \\
\hline & \multicolumn{2}{|c|}{ Control $(n=70)$} & \multicolumn{2}{|c|}{ "Study(n=70) } \\
\hline & No. & $\%$ & No. & $\%$ \\
\hline $\begin{array}{l}\text { Number of pregnancies(Gravidity): } \\
\text { - Once } \\
\text { - Twice } \\
\text { - Three times } \\
\text { - More than three times }\end{array}$ & $\begin{array}{l}0 \\
15 \\
14 \\
41\end{array}$ & $\begin{array}{l}0.0 \\
21.4 \\
20.0 \\
58.6\end{array}$ & $\begin{array}{l}10 \\
15 \\
16 \\
29\end{array}$ & $\begin{array}{l}14.3 \\
21.4 \\
22.9 \\
41.4\end{array}$ \\
\hline $\begin{array}{l}\text { Unwanted pregnancy: } \\
\text { Yes } \\
\text { No }\end{array}$ & $\begin{array}{l}40 \\
30\end{array}$ & $\begin{array}{l}57.1 \\
42.9\end{array}$ & $\begin{array}{l}45 \\
25\end{array}$ & $\begin{array}{l}64.3 \\
35.7\end{array}$ \\
\hline $\begin{array}{l}\text { Number of abortions: } \\
\text { - None } \\
\text { - One time } \\
\text { - Twice } \\
\text { - Three times or more }\end{array}$ & $\begin{array}{l}56 \\
10 \\
2 \\
2\end{array}$ & $\begin{array}{l}80.0 \\
14.2 \\
2.9 \\
2.9\end{array}$ & $\begin{array}{l}46 \\
20 \\
4 \\
0\end{array}$ & $\begin{array}{l}65.7 \\
28.6 \\
5.7 \\
0.0\end{array}$ \\
\hline $\begin{array}{l}\text { Types of abortion: } \\
\text { - Spontaneous } \\
\text { - Therapeutic abortion } \\
\text { - Induced abortion } \\
\text { - Threatened abortion } \\
\text { - Rh incompatibility } \\
\end{array}$ & $\begin{array}{l}9 \\
3 \\
0 \\
2 \\
0\end{array}$ & $\begin{array}{l}12.9 \\
4.2 \\
0 \\
2.9 \\
0.0 \\
\end{array}$ & $\begin{array}{l}10 \\
5 \\
1 \\
7 \\
1 \\
\end{array}$ & $\begin{array}{l}14.3 \\
7.2 \\
1.4 \\
10.0 \\
1.4\end{array}$ \\
\hline
\end{tabular}

Figure (1) Distribution of women regarding had received information about FP at Al-Sabeen Hospital and Al-Olofi Center, in Sana'a, 2011-2012

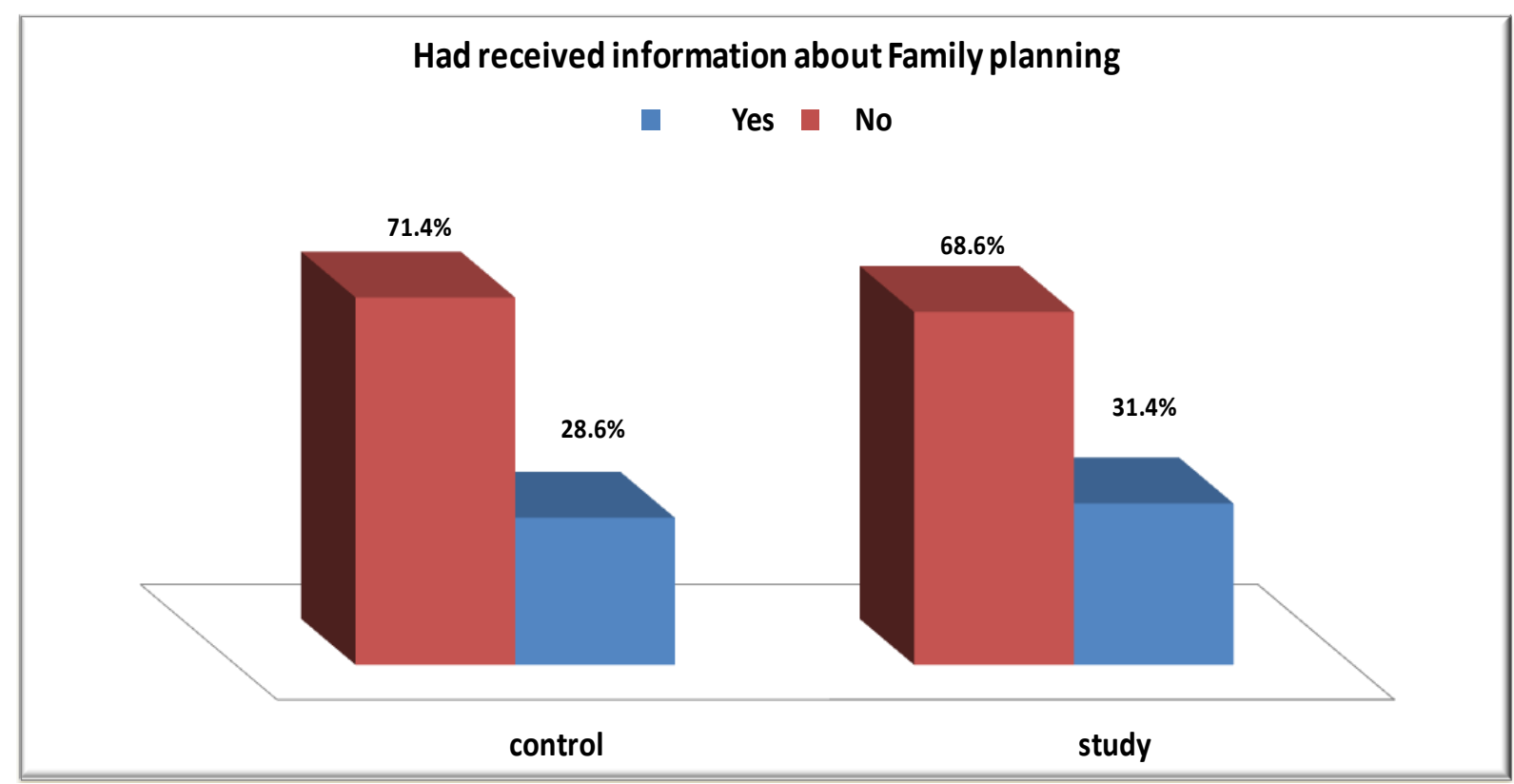


Figure (2 )Distribution of women regarding to the source of information at Al-Sabeen Hospital and Al-Olofi Center, in Sana'a 2011-2012.

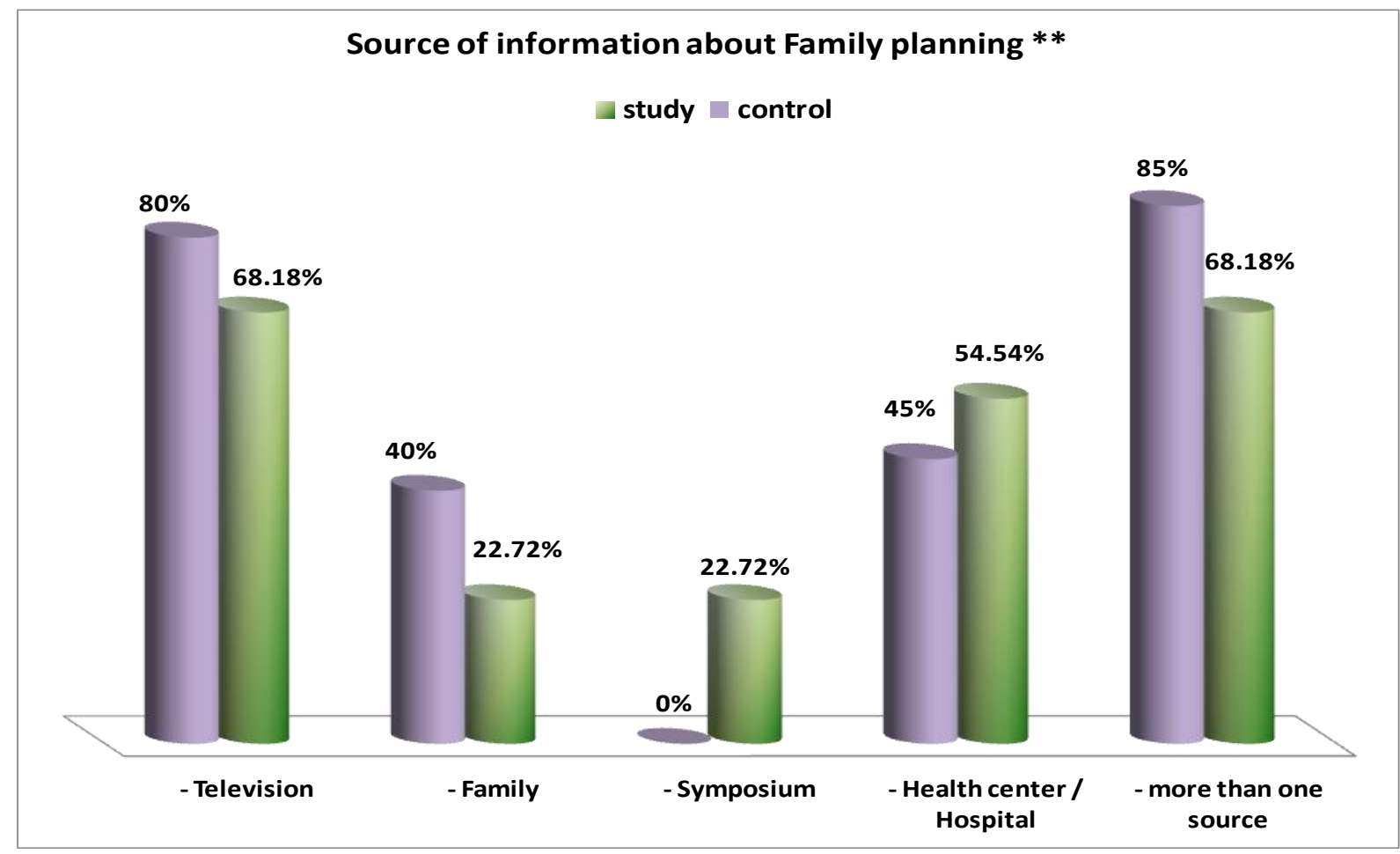

** more than one source

Figure (3) Distribution of women regarding to their total knowledge score about the FP at Al-Sabeen Hospital and Al-Olofi Center, in Sana'a, 2011-2012.

\section{Women regarding to their total knowledge score about FP}

\section{Good [ Fair}

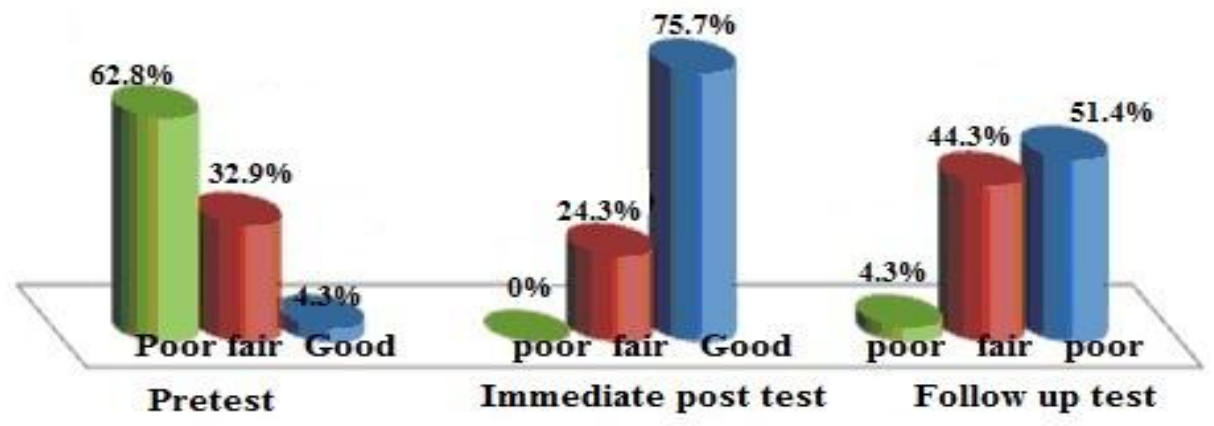


Table (3) Relation between women score of knowledge about family planning and their age.

\begin{tabular}{|c|c|c|c|c|c|c|c|c|c|c|c|}
\hline \multirow{3}{*}{ Age: (years) } & \multicolumn{4}{|c|}{ Pre- - test $\quad(n=70)$} & \multicolumn{3}{|c|}{ Post - test $(n=70)$} & \multicolumn{4}{|c|}{ Follow-up test $\quad(n=70)$} \\
\hline & poor & Fair & Good & Total & Fair & Good & Total & poor & Fair & Good & Total \\
\hline & $\%$ & $\%$ & $\%$ & $\%$ & $\%$ & $\%$ & $\%$ & $\%$ & $\%$ & $\%$ & $\%$ \\
\hline$<20$ & 4.3 & 1.4 & 0.0 & 5.7 & 4.3 & 1.4 & 5.7 & 1.4 & 2.9 & 1.4 & 5.7 \\
\hline $20-<30$ & 27.2 & 20.0 & 1.4 & 48.6 & 10.0 & 38.6 & 48.6 & 0.00 & 18.6 & 30.0 & 48.6 \\
\hline $30-<40$ & 20.0 & 10.0 & 2.9 & 32.9 & 2.9 & 30.00 & 32.9 & 1.4 & 14.3 & 17.1 & 32.9 \\
\hline $40-<49$ & 11.4 & 1.4 & 0.0 & 12.8 & 7.1 & 5.7 & 12.8 & 1.4 & 8.6 & 2.9 & 12.9 \\
\hline Total & 62.9 & 32.8 & 4.3 & 100.0 & 24.3 & 75.7 & 100 & 4.2 & 44.3 & 51.4 & 100 \\
\hline \multicolumn{8}{|l|}{$\mathrm{X}^{2} 1=4.946$} & \multicolumn{4}{|c|}{$\mathrm{X}^{2} 2=10.182$} \\
\hline \multicolumn{8}{|l|}{$\mathrm{P} 1=0.544$} & \multicolumn{4}{|c|}{$\mathrm{PII}=0.072$} \\
\hline
\end{tabular}

* Statistically significant difference

$\mathrm{x}^{2}=$ Chi-square test was used

$\mathrm{x}^{2}{ }_{1}$ means the relation between pre-test and post-test.

$\mathrm{x}^{2}{ }_{2}$ means the relation between post-test and follow-up test.

Table (4) Relation between women score of knowledge about family planning and their education of level.

\begin{tabular}{|c|c|c|c|c|c|c|c|c|c|c|c|}
\hline \multirow{3}{*}{ Educational status } & \multicolumn{4}{|c|}{ Pre- test $\quad(n=70)$} & \multicolumn{3}{|c|}{ Post - test $(n=70)$} & \multicolumn{4}{|c|}{ Follow-up test $\quad(n=70)$} \\
\hline & poor & Fair & Good & Total & Fair & Good & Total & poor & Fair & Good & Total \\
\hline & $\%$ & $\%$ & $\%$ & $\%$ & $\%$ & $\%$ & $\%$ & $\%$ & $\%$ & $\%$ & $\%$ \\
\hline Illiterate & 10.0 & 0.0 & 0.0 & 10 & 8.6 & 1.4 & 10.0 & 1.4 & 7.1 & 1.4 & 10 \\
\hline Read and write & 11.4 & 2.9 & 0.0 & 14.3 & 7.2 & 7.2 & 14.4 & 0.0 & 11.4 & 2.9 & 14.3 \\
\hline Preparatory education & 27.1 & 12.9 & 0.0 & 40.0 & 5.7 & 34.2 & 39.9 & 1.4 & 14.3 & 24.3 & 40.0 \\
\hline Secondary education & 11.4 & 14.3 & 2.9 & 28.6 & 2.9 & 25.7 & 28.6 & 1.4 & 11.4 & 15.7 & 28.6 \\
\hline Bachelor degree & 2.9 & 2.9 & 1.3 & 7.1 & 0.0 & 7.1 & 7.1 & 0.0 & 0.0 & 7.1 & 7.1 \\
\hline Total & 62.8 & 33.0 & 4.2 & 100.0 & 24.4 & 75.6 & 100 & 4.3 & 44.3 & 51.4 & 100.0 \\
\hline \multicolumn{8}{|l|}{$X^{2} 1=20.660$} & \multicolumn{4}{|c|}{$X^{2} 2=18.491$} \\
\hline \multicolumn{8}{|l|}{$\mathrm{PI}=0.001 *$} & \multicolumn{4}{|c|}{$\mathrm{PII}=0.013^{*}$} \\
\hline
\end{tabular}

* Statistically significant difference

$\mathrm{x}^{2}=$ Chi-square test was used

$\mathrm{x}^{2}{ }_{1}$ means the relation between pre-test and post-test.

$\mathrm{x}^{2}{ }_{2}$ means the relation between post-test and follow-up test.

Table (5) Relation between women score of knowledge about family planning and their occupation.

\begin{tabular}{|c|c|c|c|c|c|c|c|c|c|c|c|}
\hline \multirow{3}{*}{$\begin{array}{l}\text { Occupational } \\
\text { status }\end{array}$} & \multicolumn{4}{|c|}{ Pre- test $(n=70)$} & \multicolumn{3}{|c|}{ Post - test $(n=70)$} & \multicolumn{4}{|c|}{ Follow-up test $(n=70)$} \\
\hline & poor & Fair & Good & Total & Fair & Good & Total & poor & Fair & Good & Total \\
\hline & $\%$ & $\%$ & $\%$ & $\%$ & $\%$ & $\%$ & $\%$ & $\%$ & $\%$ & $\%$ & $\%$ \\
\hline Housewife & 55.7 & 15.7 & 0.0 & 71.4 & 22.9 & 48.6 & 71.4 & 4.3 & 38.6 & 28.6 & 71.4 \\
\hline Employee & 7.1 & 15.7 & 2.9 & 25.7 & 1.4 & 24.3 & 25.7 & 0.0 & 5.7 & 20.0 & 25.7 \\
\hline Student & 0.0 & 1.4 & 1.4 & 2.9 & 0.0 & 2.9 & 2.9 & 0.0 & 0.0 & 2.9 & 2.9 \\
\hline Total & 62.9 & 32.9 & 4.3 & 100.0 & 24.3 & 75.7 & 100 & 4.3 & 44.3 & 51.4 & 100.0 \\
\hline \multicolumn{8}{|l|}{$X^{2} 1=22.157$} & \multicolumn{4}{|c|}{$X^{2} 2=9.446$} \\
\hline \multicolumn{8}{|l|}{$\mathrm{PI}=0.001 *$} & \multicolumn{4}{|c|}{$\mathrm{PII}=0.031^{*}$} \\
\hline
\end{tabular}

* Statistically significant difference

$\mathrm{x}^{2}=$ Chi-square test was used

$\mathrm{x}^{2}{ }_{1}$ means the relation between pre-test and post-test.

$\mathrm{x}_{2}^{2}$ means the relation between post-test and follow-up test. 
Table (6) Relation between women score of knowledge about family planning and their number of years of marriage.

\begin{tabular}{|c|c|c|c|c|c|c|c|c|c|c|c|}
\hline \multirow{3}{*}{ years of marriage } & \multicolumn{4}{|c|}{ Pre- test $\quad(n=70)$} & \multicolumn{3}{|c|}{ Post - test $(n=70)$} & \multicolumn{4}{|c|}{ Follow-up test $\quad(n=70)$} \\
\hline & poor & Fair & Good & Total & Fair & Good & Total & poor & Fair & Good & Total \\
\hline & $\%$ & $\%$ & $\%$ & $\%$ & $\%$ & $\%$ & $\%$ & $\%$ & $\%$ & $\%$ & $\%$ \\
\hline$<5$ & 21.4 & 7.1 & 0.0 & 28.6 & 11.4 & 17.1 & 28.6 & 1.4 & 12.9 & 14.3 & 28.6 \\
\hline $5-<10$ & 12.9 & 12.9 & 2.9 & 28.6 & 1.4 & 27.1 & 28.6 & 1.4 & 10.0 & 17.1 & 28.6 \\
\hline $10-<15$ & 17.1 & 7.1 & 1.4 & 25.7 & 5.7 & 20.0 & 25.7 & 0.0 & 10.0 & 15.7 & 25.7 \\
\hline $15>$ & 11.4 & 5.7 & 0.0 & 17.1 & 5.7 & 11.4 & 17.1 & 1.4 & 11.4 & 4.3 & 17.1 \\
\hline Total & 62.9 & 32.9 & 4.3 & 100.0 & 24.3 & 75.7 & 100 & 4.3 & 44.3 & 51.4 & 100.0 \\
\hline \multicolumn{8}{|l|}{$\mathrm{X}^{2} 1=7.714$} & \multicolumn{4}{|c|}{$X^{2} 2=5.872$} \\
\hline \multicolumn{8}{|l|}{$\mathrm{PI}=0.045^{*}$} & \multicolumn{4}{|c|}{$\mathrm{PII}=0.389$} \\
\hline
\end{tabular}

* Statistically significant difference

$\mathrm{x}^{2}=$ Chi-square test was used

$\mathrm{x}^{2}{ }_{1}$ means the relation between pre-test and post-test.

$\mathrm{x}_{2}{ }_{2}$ means the relation between post-test and follow-up test.

Table (7) Relation between women score of knowledge about family planning and their number of living children.

\begin{tabular}{|c|c|c|c|c|c|c|c|c|c|c|c|}
\hline \multirow{3}{*}{ Number of living children } & \multicolumn{4}{|c|}{ Pre- test $\quad(n=70)$} & \multicolumn{3}{|c|}{ Post - test $(n=70)$} & \multicolumn{4}{|c|}{ Follow-up test $\quad(n=70)$} \\
\hline & poor & Fair & Good & Total & Fair & Good & Total & poor & Fair & Good & Total \\
\hline & $\%$ & $\%$ & $\%$ & $\%$ & $\%$ & $\%$ & $\%$ & $\%$ & $\%$ & $\%$ & $\%$ \\
\hline None & 7.1 & 2.9 & 0.0 & 10.0 & 7.1 & 2.9 & 10.0 & 1.4 & 7.1 & 1.4 & 10.0 \\
\hline $1-4$ & 34.3 & 21.4 & 4.3 & 60.0 & 8.6 & 51.4 & 60.0 & 1.4 & 21.4 & 37.1 & 60.0 \\
\hline $5-6$ & 15.7 & 5.7 & 0.0 & 21.4 & 4.3 & 17.1 & 21.4 & 0.0 & 12.9 & 8.6 & 21.4 \\
\hline $7+$ & 5.7 & 2.9 & 0.0 & 8.6 & 4.3 & 4.3 & 8.6 & 1.4 & 2.9 & 4.3 & 8.6 \\
\hline Total & 62.9 & 32.9 & 4.3 & 100.0 & 24.3 & 75.7 & 100 & 4.3 & 44.3 & 51.4 & 100.0 \\
\hline \multicolumn{8}{|l|}{$X^{2} 1=11.571$} & \multicolumn{4}{|c|}{$X^{2} 2=10.740$} \\
\hline \multicolumn{8}{|l|}{$\mathrm{PI}=0.006^{*}$} & \multicolumn{4}{|c|}{$\mathrm{PII}=0.060$} \\
\hline
\end{tabular}

* Statistically significant difference

$\mathrm{x}^{2}=$ Chi-square test was used

$\mathrm{x}^{2}{ }_{1}$ means the relation between pre-test and post-test.

$\mathrm{x}^{2}{ }_{2}$ means the relation between post-test and follow-up test.

Table (1) shows the distribution of the studied women and the control group regarding the Sociodemographic characteristics. It was found that nearly half of the studied women (48.6\%) aged 20 years and less than 30years while more than half of the control group (57.1\%) aged 30 years and less than 40 years.The mean age of the studied group was (mean \pm SD $2.53 \pm 0.793$ ) while the mean age of the control group was (mean \pm SD $2.81 \pm 0.666$ ) .

Regarding the women educational level, it was clear that $(40 \%)$ of studied group and $(45.7 \%)$ of the control group had preparatory education. According the women occupation, it was found that most women in control and study group were housewife $80.0 \%$ and $71.4 \%$ respectively.
Regarding years of marriage, the highest percentage was $(28.6 \%)$ and their years of marriage were between less than five years and less than ten years of the study group. On the other hand, the highest percentage of women $(34.3 \%)$ and their years of marriage were between five years and less than ten years of the control group. Concerning the number of living children, it was found that the highest percentage of women who had between one to four children of both study and control group were representing $60.0 \%$, and $55.7 \%$ respectively.

Table (2) shows the distribution of the women regarding their obstetric history. It was clear that the number of pregnancies were more than two fifth $(41.4 \%)$ of the study group for three or more times while (58.6\%) about two third for the control group. 
Concerning to the unwanted pregnancy, the table shows that $64.3 \%$ and $57.1 \%$ respectively of both study and control group had unwanted pregnancy. According to the number of abortions, it showed that $28.6 \%$ and $14.2 \%$ respectively of both study and control group had at least one time abortion. Regarding the types of abortion, $14.3 \%$ and $12.9 \%$ respectively of both study and control group had spontaneous abortion.

Figure (1) illustrates the distribution of women regarding their family planning information. It was found that about nearly three quarters $(71.4 \%)$ of the control group and more than two third $(68.6 \%)$ of the studied group had not received any information.

Figure (2) shows the source of information about family planning, it was clear that $85 \%$ and $68.18 \%$ respectively) of control and study group received from more than one source. This is followed by $80 \%$ and $68.18 \%$ respectively) who had received information from information from TV. While $45 \%$ and $54.54 \%$ respectively of control and study group received information from health center / hospital.

Table (3) presents the relation between women score of knowledge about family planning and their age. It was found that, there was no statically significant difference between women age and their knowledge $(\mathrm{PI}=0.544)$ in pretest, and no statistically significant difference (PII=0.072) in follow up test.

Table (4) shows the relation between women score of knowledge about family planning and their education of level. It was found that, there was highly statistically significant difference between women knowledge and their education $(\mathrm{PI}=0.001)$ in immediate posttest as well as statistically significant difference $(\mathrm{PII}=0.013)$ in follow up.

Table (5) shows the relation between women knowledge about family planning and their occupation. It was found that, there was highly statistically significant difference between women knowledge and their occupation status $(\mathrm{PI}=0.001)$ in immediate posttest, and statistically significant difference $(\mathrm{PII}=0.031)$ in follow up.

Table (6) reveals the relation between women knowledge about family planning and their number of years of marriage. It was found that, there was statistically significant difference between women knowledge and their number of years of marriage $(\mathrm{PI}=0.045)$ in immediate posttest but no statistically significant difference (PII=0.389) in follow up test.

Table (7) shows the relation between women knowledge about family planning and their number of living children. It was found that, there was highly statistically significant difference between women knowledge and their number of years of marriage $(\mathrm{PI}=0.006)$ in immediate posttest, but no statistically significant difference (PII=0.060) in follow up test.

\section{Discussion:}

Family planning allows couples to anticipate or attain their desired number of children, control spacing between pregnancies and timing of births. It is achieved through the use of contraceptive methods and the treatment of involuntary infertility. A woman's ability to space and limit her pregnancies has a direct impact on her health and well-being as well as on the outcome of each pregnancy (WHO, 2013).

There are different family planning methods. Each of these methods suits a particular need, desire or condition of a couple. What is important for each one of us is to choose a family planning method that meets our needs and conditions (Aradhya, 2009). Family planning methods can be divided based on several criteria such as natural or artificial, traditional or modern, temporary or permanent, male or female and oral or injectables or IUCDs (Almualm, 2007).

In Yemen, women face enormous challenges and obstacles. Young girls receive little more than a primary school education, and then are often married by the age of eight. The population number in Yemen was reported 23.69 millions persons in 2009, according to the International Monetary Fund (IMF, 2009). According to the final results of the 2004 census, women represent 49 percent of the total population ( Mwanawasa, 2007).

The present study aimed to evaluate the impact of an educational program of family planning intervention upon women in Sana'a city, Yemen.

Considering their age, the current study (table1) showed that, the age of nearly half $(48.6 \%)$ of the studied women ranged from twenty to thirty years old. This may be due to Yemeni women in this age focus about taking care for their heath. Therefore, they follow up and attended hospital or centers for any health problem. This disagreed with (Rabbee, 2003) who reported that, a significant percentage of young women are below the age of 14 in Yemen.

Regarding the educational status, the present study (table1) found that, $40 \%$ of the studied women received preparatory education. This result is similar to (Rabbee, 2003) who found that women's access to education has increased significantly in basic education classes. Also, agree with (UNDP, 2005 \& Gunter, 2012) estimated that about $43 \%$ of females attend school in basic education programs.

Regarding the occupation, the present study (table1) showed that, more than two third $(71.4 \%)$ of the studied women were housewives. This is due to the fact that most husbands do not want their wives to be employees; they prefer women to be housewives. Besides, women get more load and cannot manage their responsibilities at home and work. This agree 
with study in Yemen by (Mashrai et al., 2005) who found that $77 \%$ of women were housewives.

However, regarding the years of marriage, the results of the present study (table1) indicated that, more than one quarter of the studied women were married for $<5$-<10years. This finding is in contrast with the study in Mahidol at Bangladesh by (Yunus, 2006) which mentioned that about one third $(32.57 \%)$ of the participants were married for $\geq 16$ years.

As for the number of living children, the results of the present study (table 1) indicated that, three fifth (60\%) of the studied women had from one to four children. This finding agreed with the study in Washington by (Seyfried, 2011) which found that more than half $(58.8 \%)$ of the studied women had from one to four children. On the other hand, the study agreed with (Fahimi et al., 2012) who reported that more than three quarter of Yemeni women had between one and four children.

Regarding the number of pregnancies, the current study (table 2) revealed that, more than two fifth $(41.4 \%)$ of the studied women had $<3$ gravidity. This result is inconsistent with the study applied in Alexandria by (Abd El Salam, 2008) who found that indicated that more than half $(58.67 \%)$ of women had $<3$ gravidity.

Concerning unwanted pregnancy, the present studying (table 2) revealed that, more than half of the control group and about two third of the studied group had unwanted pregnancies. This might be because of unplanned pregnancy or because nearly three quarter of both group did not receive information about birth control. This result is similar to a previous study in Yemen conducted by (Fahimi et al., 2012) who reported that $58 \%$ of pregnant women had pregnancies which were unintentional (wanted later or not wanted at all). Also, the present study is inconsistent with (Seyfried, 2011) in Washington who found out that about two thirds wanted pregnancies while more than one third did not.

Regarding the number of abortion, the results of the current study (table 2) made it clear that, nearly one third of the studied women had abortions. This result disagrees with the study conducted in Alexandria by (Abd El Salam, 2008) who highlighted that (14\%) of women had abortions. In addition, the findings of the present study disagrees with (Issa, 2004) in Alexandria who reported that $(14.4 \%)$ of women had abortions.

Considering receiving information about family planning, the present study (Figure 1) showed that, more than two third of the studied group and nearly three quarter of the control group had not received any information. This may be due to lack of source of information provided about birth control as well as the limiting need in getting education about having space between pregnancies. Another reason may be the lack of counseling sources as most of nurses do not give health education about FP to women in postnatal care. This is in contrast with the (Nicaragua, 2008) in Dominican Republic which reported that, one quarter did not receive information about family planning.

Concerning the source of information women receive about family planning (Figure 2), more than one fifth of both groups (studied and control) in the present study received information about family planning from TV. This result is inconsistent the study conducted in kuruchikuppam Pondicherry in India by (Rajesh et al., 2003) who found that more than half of the sample received information about family planning from Mass media.

Regarding the total women knowledge score about the family planning, the present study (Figure 3) found that, the majority of the studied women had a poor score on pretest, improved good score on immediate post test, and remaining in good score with slight decreased in percentage on follow up test. Therefore, there were highly statically significant differences $(\mathrm{PI}=0.001)$, and statically significant differences $(\mathrm{PII}=0.006)$. This finding was matching with the results of other studies conducted in Jordan by (Mahamed et al., 2012) which showed that, there was a significant improvement in respondents' knowledge educational program in the experimental group $(\mathrm{p}<0.001)$.

As regards the relation between studied women' knowledge and age, the current study (table 3) indicted that, women who aged between 20 years and less than 30 years had poor knowledge before the application of the program. However, their knowledge improved after the application of the program. And also, there was good knowledge with slight decreased in the percentages on follow up test. So there was highly statically significant difference between women' knowledge and age on pretest and immediate posttest $(\mathrm{p}=0.004)$. This might be attributed to the number of women who aged between 20 years and less than 30 years more than other ages. This result disagreed with (Oyefara, 2012) in Yoruba Society, Nigeria who revealed that older mothers had relatively better knowledge about methods of family planning.

Concerning the relation between studied women' knowledge and education status, the present study (table 4) revealed that, the scores of knowledge were better among the women who had preparatory education than among those who "read and write" in immediate and post application program. Although declined in the percentages on late follow up of preparatory education with highly statically 
significant difference between women' knowledge and education status on pretest and immediate posttest $(\mathrm{p}=0.001)$. It may be related that women who had preparatory education understood the information better due to different sources of knowledge from schools, families and were less affected by rumors.

According to the relation between studied women' knowledge and occupation status, the current study (table 5) indicated that the scores of knowledge were better among the housewife women than among employee women in immediate post application the program. (48.6\%) of housewife and (24.3\%) of employee had obtained a good score knowledge while declined in the percentages on late follow up $(28.6 \%)$ of housewife and $(20.0 \%)$ of employee had obtained a good score of knowledge with statically significant difference between women' knowledge and education status on immediate posttest and follow up test $(\mathrm{p}=0.031)$. It may be related to the number of housewife women more than the number of employee women. This finding agreed with (Mohamed, 2006) in Beni-sueif who found that, there were statistically significantly associated with women' knowledge and their occupation status $(\mathrm{p}<0.001)$.

Regarding the relation between the knowledge of the studied women and the years of marriage, the present study (table 6) found that, the scores of knowledge were better among the women whose years of marriage $5-<10$ than less 5 years in immediate posttest. On late follow up, these percentage of these scores declined, but had obtained a good score of knowledge with statically significant difference between women' knowledge and years of marriage on pretest and immediate posttest $(\mathrm{p}=0.045)$. This might be due to the fact that women' knowledge and experiences were affected by years marriage (duration of marriage). This finding was matching to the results of the study conducted by (Narzary, 2009) in India which reported that, there was a very distinct positive marital duration and knowledge about contraceptive methods.

As regards to the relation between studied women' knowledge and number of living children, the present study (table 7) showed that, the scores of knowledge was better among women who had 1-4 children than among those who did not have children $(51.4 \%$ and $2.9 \%$ ); they had gained a good score of knowledge post application the program while declined in the percentages on follow up test $(37.1 \%$ and $1.4 \%)$ with statically significant difference between women' knowledge and number of living children on pre test and immediate post test $(\mathrm{p}=0.006)$. This might be due to the fact that women who had been pregnant become more experiences and knowledgeable in birth control. This finding was matching with the results of study conducted in Arab sector in Israel by ( $\boldsymbol{A} \boldsymbol{b} \boldsymbol{u}$ Ahmed et al., 2003) which showed a significant correlation between the women with a low level of education and more than 7 children. As the educational level rises, there are fewer children in the family $(\mathrm{P}<0.001)$.

\section{Conclusion and Recommendations}

Based on the results of the present study it can be concluded that; studied women knowledge about family planning were poorly scored on pretest, improved to good score on immediate post test, and remaining in good score with slight decreased in percentage on follow up test. The researcher came up with the following recommendations:

1-Family planning program should concentrate on young age women and offer spacing method to them while offer prolonged or permanent methods for old age women.

2. Improved quality of counseling for couples need to address fear of side effects through helping the women to receive adequate information about the correct way of using the methods and the related problems that women probably encounter to overcome contraceptive failure and discontinuation.

3 -Family planning program should involved men as well as women. Men involvement in FP counseling will reduce opposition to FP programs and also encourage their wives to use contraceptive methods.

4- Increase quality of FP services staff through training program and updating information.

5- Design and implement a strategy to ensure that all primary health care clinics, reproductive health centers and maternity units nationwide are routinely offering counseling on FP and providing appropriate methods for their clients.

\section{References:}

1. Abd El Salam H.A., (2008): Factors Associated with Intrauterine Devices Discontinuation in Alexandria, master degree, Faculty of Nursing, University of Alexandria. Pp: 23- 33.

2. Abu Ahmed A., Tabenkin H., and Steinmetz D., (2003): Knowledge and Attitude among Women in the Arab Village Regarding Contraception and Family Planning and the Reasons for Having Numerous Children, Department of Family Medicine, Herefuah ,Vol.142(12),Pp: 822-5,879,878.

3. Almualm Y.K., (2007): Knowledge, attitude and practice of husbands towards modern family planning in Mukalla, published master degree, University Sains Malaysia.

4. Aradhya K., (2009): Task shifting is expanding the roles of family planning providers Family 
Health International, Research Triangle Park, USA, Africa Health .Reproductive Health. Pp: 3639.

5. El - Houfey A, (2007): Knowledge and Practice of Dental Health Care Providers toward Crossinfection Control Measures in Assiut city, master thesis,Faculty of Nursing Assiut University.

6. Fahimi F.R., Monem A.A., Ashford L., and EL-Adawy M,.(2012):Women's Need For FamilyPlanning in Arab Countries, UNPA. Available at: www.prb.org

7. Gold R.B., Sonfield A., Richards L.C., Frost J. J., (2009): Next Steps for America's Family Planning Program Leveraging the Potential of Medicaid ,Title $X$ in an Evolving Health Care System; New York, Guttmacher Institute. Pp: 623.

8. Gunter N.D., (2012): Measuring Women's Status in Yemen, $\mathrm{D}^{3}$ Systems. Available at: www. $\underline{\mathrm{D}^{3} \text { Systems.com }}$

9. International Monetary Fund, (2009): Yemen population. Available at:http://www.tradingeconomics.com/yemen/popu lation-imf-data.html

10. Issa M.A., (2004): Extent of Male Involvement in Family Planning, master degree, Faculty of Nursing, University of Alexandria. Pp: 40-48.

11. Kaliyaperumal K., (2004): Guideline for Conducting a Knowledge Attitude and Practice (KAP) Study, Community Ophthalmology. AECS Illumination, Vol. IV,(1), Pp: 7-9.

12. Mahamed F., Parhizkar S., and Shirazi A.R., (2012): Impact of Family Planning Health Education on the Knowledge and Attitude among Yasoujian Women, Global Journal of Health Science,Vol.4(2); Pp: 110-118.

13. Mashrai R., Al-Shaibah Q., AL-Shami B., ALWeshali H., and AL-Yafi A., (2005): Determined the Factors Influencing the Use of Contraception among Married Women in Different Yemeni Governorates, Faculty of Medicine and Health Science in Sana'a University. Pp: 56- 68.

14. Minister of Public Health and Population., (2009): Annual statistical health reporting 2009.Available at:http://www.mophye.org/arabic/doc/report 2009.pdf

15. Mohamed A.A., (2006): Knowledge and Attitude about Reproductive Health among Married Women (teenage and more than 25 years) in Maternity Outpatient Clinics at Beni-Sueif University Hospital, master degree, Faculity of Nursing, Assiut, Pp: 39-40.

16. Mwanawasa L.P.,( 2007): Central Statistical Office Strategic Plan, Strategic Plan (2003 -
2007),President of the Republic of Zambia,Pp:516.

17. Narzary B.N., (2009): Knowledge and Use of Contraception among Currently Married Adolescent Women in India, Fakir Mohan University, Vyasa Vihar, Balasore, Orissa, India, Stud Home Comm Sci, 3(1) 43-49.

18. Nicaragua H., (2008): Promoting Family Planning during the Postpartum Period can increase Contraceptive Acceptance, Population Council, Or Summary 74, Frontiers USA, Pp: 1-5.

19. Oyefara J. L., (2012): Women Age at First Birth and Knowledge of Family Planning Methods in Yoruba Society, Nigeria, Journal of Sociological Research, Vol.3, (2), Pp: 249-266.

20. Rabbee A., ( 2003):Adolescent Reproductive Health in Yemen, Status Policies Program and Issues. Policy Project. Sana'a. Pp: 3- 18.

21. Rajesh R.S., Premarajan K.C., Narayan K.A., Mishra A.K., (2003): Rapid Appraisal of Knowledge Attitude and Practice Related to Family Planning Methods among Men within 5 Years of Married Life, India J. Prev. Soc. Med Vol. 34 (1\&2), Pp: 62-67.

22. Saleh M., (2009): Family Planning, The 2008 Humanitarian of the Year has Advanced Health Care for Yemen's Women Through USAIDFunded

Project.Availableat:http://www.usaid.gov/our_wo rk/global_health/pop/news/saleh_award.html

23. Seyfried L., (2011): Family Planning and Maternal Health, The Effect of Family Planning and Maternal Health in the Democratic Republic of Congo, published master thesis, Faculty of Georgetown University. Washington, DC. , Pp: 21-27.

24. Shaw D., (2012): The ABC's of family planning, Canada, The Partnership for Maternal Newborn Health, WHO, FRCSC; Pp: 1-15.

25. United Nations Development Programme, (2005):Barriers to use of Family Planning Services in Malawi, Findings from Focus Group Discussions, Reproductive Health Research, Opportunities and Choices, UNFPA, University of Southampton. Pp: 1- 6.

26. United States Agency for International Development, (2009): Family Planning, The 2008 Humanitarian of the Year has Advanced Health Care for Yemen's Women Through. Pp: 12.

27. World Health Organization, (2008): Family planning. Available at:http://www.who.int/topics/family_planning/en/i $\underline{\text { ndex.html }}$ 
28. World Health Organization, (2013): $\mathrm{PMNCH}$ Fact Sheet, Maternal mortality, Millennium Development Goal (MDG) 5, Partnership for Maternal, Newborn \& Child Health. Available at:http://www.who.int/pmnch/media/press_materi als/fs/fs mdg5 maternalmortality/en/index.html

29. Yunus M.D., (2006): Factors Related to the Acceptance of Family Planning Methods among the Married Women of Reproductive Age in Methapukur Upazila,Rangpur District, Bangladesh, published master thesis, Faculty of Graduate Studies Mahidol University, Pp: 37-74 